\title{
A Peste Negra e o imaginário religioso nas obras de Jean Delumeau
}

\author{
Black Pest and religious imaginary in the works of Jean Delumeau
}

Sergio Luiz Marlow ${ }^{1}$

Wanderley Pereira da Rosa**

doi) $\underline{\text { https://doi.org/10.29327/256659.12.1-6 }}$

\begin{abstract}
Resumo
O ano de 2020 é um ano sem paralelos na história recente da humanidade tendo em vista a Pandemia do Novo Coronavirus (Covid-19). Neste sentido, torna-se oportuna a reflexão sobre outra importante epidemia que assolou a humanidade, principalmente entre os séculos XIV e XVIII: a Peste Negra. O ano de 2020 também marca o falecimento do historiador francês Jean Delumeau, especialista em História das mentalidades e História da Igreja Cristã. O presente artigo, desta forma, faz uma homenagem ao célebre historiador destacando suas principais obras sobre o assunto $(1989$; 1993; 2003), bem como analisando suas contribuições sobre o imaginário e a religiosidade medieval em face da Peste Negra. A reflexão sobre epidemias que assolaram a humanidade também contribui para pensarmos a vida pós-pandemia do Tempo Presente.
\end{abstract}

Palavras-chave: Imaginário medieval. Religiosidade. Epidemias.

\section{Abstract}

2020 is a year unparalleled in recent human history in view of the New Coronavirus Pandemic (Covid-19). In this sense, it is opportune to reflect on another important epidemic that struck humanity, especially between the 14th and 18th centuries: the Black Death. The year 2020 also marks the death of French historian Jean Delumeau, an expert on the history of mentalities and the history of the Christian Church. The present article, in this way, pays homage to the celebrated historian, highlighting his main works on the subject $(1989 ; 1993 ; 2003)$, as well as analyzing his contributions on medieval imagery and religiosity in the face of the Black Death. Reflection on epidemics that plagued humanity also contributes to thinking about the post-pandemic life of the Present Time.

Keywords: Medieval imaginary. Religiosity. Epidemics.

1Pós-doutor em História junto ao Programa de Pós-graduação em História da Universidade Federal do Espírito Santo (UFES) e doutor em História Social pela Universidade de São Paulo (USP). Docente da Faculdade Unida de Vitoria (FUV). E-mail: sergio@fuv.edu.br.

** Doutor em Teologia pela Pontificia Universidade Católica do Rio de Janeiro (PUC-RJ). Docente de História do Cristianismo e Diretor-Geral da Faculdade Unida de Vitória (FUV). E-mail: wanderley@fuv.edu.br 
Eu me abandono em Ti. Entrarei na terra. Contudo, que meu último pensamento seja o da confiança Jean Delumeau (1923-2020)

\section{Introdução}

O ano de 2020 será lembrado na história da humanidade como o ano da Pandemia de um novo Coronavirus descoberto no final de 2019, na China, que "recebeu o nome oficial de Covid-19, em 11 de fevereiro [de 2020]: um acrônico do termo 'doença por corona vírus' em inglês (corona vírus diseased 2019)" (Fiocruz, 2020). Apesar das recomendações de quarentena e isolamento social e os reflexos disso na vida das pessoas em sociedade, presenciamos diariamente a triste informação de milhares de vidas perdidas. Tomando como referência dos dados a data de 10 de agosto de 2020, aproximadamente cerca de 736 mil pessoas morreram em decorrência da Covid-19 no planeta, sendo o Brasil o segundo maior país atingido, com aproximadamente 100 mil mortes, atrás apenas dos Estados Unidos da América.

Provavelmente, nenhum outro evento de 2020 será páreo para a Pandemia da Covid-19 e as devastadoras consequências na vida da população mundial do Tempo Presente. Nota-se, aliás, referências à realidade que surge para a humanidade, especialmente através do termo "novo normal", ou seja, uma série de ações e comportamentos que irão nortear o ser humano em suas relações cotidianas em tempos pós-pandêmicos.

No entanto, além do catastrófico número de vítimas fatais do vírus, também o ano de 2020 marca o falecimento de um dos grandes historiadores do século XX e do Tempo Presente: o francês Jean Delumeau. Bruno Leal Pastor de Carvalho, em site especializado na área de História, assim informa: "morreu nesta segunda-feira, 13 de janeiro [de 2020], o historiador Jean Delumeau. [...] o pesquisador francês estava com 96 anos de idade e deixa como legado diversos livros e artigos no campo da História do Cristianismo e da História das Mentalidades" (Carvalho, 2020, p. 1).

Na revista online do Instituto Humanitas Unisinos, encontramos uma breve biografia do historiador Jean Delumeau, assim apresentado:

Nascido em 1923, o historiador e acadêmico francês Jean Delumeau é ex-aluno da École Normale Supérieure, professor titular de História, membro da Escola Francesa de Roma e doutor em Letras. Ensinou história na Escola Politécnica, na Universidade 
deRennes II, na Escola Prática de Altos Estudose na Universidade de Paris I. No Collège de France, ocupou de 1975 a 1994 a cadeira de História das Mentalidades Religiosas no Ocidente Moderno (Revista IHU online, 2020a, grifos do autor).

Conforme o artigo Jean Delumeau: um historiador entre o medo e a esperança, Delumeau continuou trabalhando até os seus últimos dias, pesquisando, escrevendo e, inclusive, comparecendo às reuniões da Académie des Inscriptions et Belles-Lettres, em Paris (Revista IHU online, 2020b). Várias gerações de historiadores reconhecem Jean Delumeau como um dos grandes professores que revitalizou as pesquisas relacionadas à história religiosa da Europa entre fins do Medievo e início da Idade Moderna, ampliando o leque de perspectivas na área(Revista IHU online, 2020b).

O também historiador Peter Burke, ao analisar as principais linhas de pesquisa histórica dentro da $3^{a}$ geração da Escola dos Annales, destaca a influência de Delumeau nas pesquisas relacionadas à história das mentalidades e da religião, com especial atenção para a questão do medo e da culpa no período Medieval. Segundo Burke,

\begin{abstract}
Jean Delumeau, que iniciara a carreira como historiador socioeconômico, transferiu suas preocupações com a produção de alumem nos estados papais para o problema da história cultural. Sua primeira tentativa foi no sentido da história da Reforma [Protestante] e da denominada "descristianização" da Europa. Mais recentemente, Delumeau voltou-se para a psicologia histórica no sentido febvriano do termo, e escreveu uma ambiciosa história do medo e da culpa no Ocidente, discriminando "os medos da maioria (o mar, fantasmas, pragas, pestes e fome) dos medos da 'cultura dominante' (satã, judeus, mulheres - principalmente feiticeiras)" (Burke, 1997, p. 84).
\end{abstract}

Também conforme Pieroni (2011), Jean Delumeau escreveu mais de vinte obras relacionadas, além da questão do Medo e da Peste Negra que aqui serão abordados, ao Cristianismo e a vários de seus dogmas, como o Paraíso e o Juízo Final.

Delumeau, em produções historiográficas no século XX, notabilizou-se por algumas das mais importantes obras relativas a outra notável epidemia que ceifou grande quantidade de vidas humanas, especialmente entre os séculos XIV e XVIII: "mais frequentemente, na Europa, tratou-se da Peste, sobretudo durante quatro séculos que correm entre 1348 e 1720" (Delumeau, 1993, p. 107). O refe- 
rido historiador dedicou atenção à Peste Negra e às consequências desta terrivel epidemia na vida de milhares e milhares de pessoas nos séculos antes mencionados.

Queremos, então, abordar a produção historiográfica deste respeitabilíssimo historiador francês a respeito da Peste Negra que grassou parte da Europa e do Oriente, destacando os acontecimentos ocorridos na Peste entre os anos de 1348-1350, mas também abordando os vários ciclos da epidemia que ocorreram em décadas e séculos posteriores. Buscaremos compreender a análise realizada por Delumeau em três de suas principais obras: Nascimento e afirmação da Reforma, traduzida para a língua portuguesa no ano de 1989; História do medo no Ocidente (1300-1800), uma cidade sitiada, traduzida para a língua portuguesa na edição de 1993, e O pecado e o medo: a culpabilização no Ocidente (séculos 1318), traduzida para a língua portuguesa em dois volumes no ano de 2003.

Desta forma, o presente artigo tem por objetivo compreender, nas pesquisas de Jean Delumeau, o imaginário medieval e, de maneira singular, o imaginário religioso daquela época, desta feita, homenageando também este importante historiador. Ao mesmo tempo em que vivemos uma época de Pandemia, queremos refletir sobre outra epidemia que assolou séculos no mundo, a epidemia da Peste Negra, destacando-se então de que forma Jean Delumeau precisou historicamente este acontecimento e os reflexos no imaginário religioso das pessoas que viviam nos tempos do Medievo.

\section{Seria a Reforma Protestante consequência da Peste Negra?}

Utilizamos especialmente duas das obras de Delumeau, acima mencionadas, como referências para a compreensão da Peste Negra na Europa Medieval, na perspectiva do historiador, enfatizando o imaginário religioso das pessoas envolvidas nesta epidemia. Além destas, há outra premissa levantada por Delumeau, de que a Peste Negra também colaborou para que o processo religioso desencadeado no século XVI - a Reforma Protestante - se concretizasse, visto que havia, por grande parte da população europeia, uma "angústia coletiva" provocada por vários fatores, entre eles a epidemia da Peste Negra.

Tal reflexão é levantada por Delumeau em outra importante obra de sua autoria, Nascimento e afirmação da Reforma, na qual descreve com grande competência o processo histórico que culminou na Reforma Protestante a partir da Alemanha no século XVI, expandindo-se por grande parte da Europa, bem como 
a Contrarreforma proposta pela Igreja Católica Apostólica Romana em defesa de sua doutrina e fé.

No capítulo introdutório desta obra, Delumeau questiona o "porquê da Reforma Protestante" e, em especial, os motivos de ter ocorrido no século XVI. O que teria levado a esse acontecimento, de contraposição a ensinamentos e práticas da igreja oficial do Sacro Império Romano Germânico - a Igreja Católica Apostólica Romana - pelo então frei agostiniano Martinho Lutero (1483-1546), desencadeando o processo de reforma da Igreja em pleno século XVI?

Delumeau, por exemplo, questiona o fato de se levantar como motivo principal da Reforma Protestante os abusos que ocorriam na igreja da época. Afirma Delumeau: "A tese segundo a qual os Reformadores teriam deixado a Igreja romana porque ela estava repleta de devassidões e impurezas é insuficiente" (Delumeau, 1989, p. 59). Em séculos anteriores à Reforma Protestante, abusos de toda a ordem na Igreja já ocorriam e nem por isso resultaram em um processo de ruptura tão dramática como o ocorrido a partir do anúncio e divulgação das noventa e cinco Teses de Martinho Lutero.

Delumeau, então, responde o porquê de a Reforma Protestante ter tido êxito a partir do século XVI. Segundo Delumeau, uma série de eventos contribuiu ao que chamou de "a resposta religiosa a uma grande angústia coletiva" (Delumeau, 1989, p. 60), da qual fazia parte a Peste Negra:

Se tantas pessoas na Europa, de níveis culturais e econômicos diferentes, optaram pela Reforma, foi por esta ter sido em primeiro lugar uma resposta religiosa a uma grande angústia coletiva. A guerra dos Cem Anos, a Peste Negra, numerosas crises, a loucura de Carlos VI, o Grande Cisma que se prolongou durante trinta e nove anos ante à estupefação indignada do mundo cristão, as guerras das Duas Rosas, as guerras hussitas, o desaire do grande Estado burguinhão com a morte trágica de Carlos, o Temerário, a ameaça turca crescente contra a qual se põem a rezar todos os dias o Ângelus, tantos acontecimentos que abalaram e desorientaram os espíritos (Delumeau, 1989, p. 60, grifo nosso).

É verdade que Delumeau, na obra sobre o nascimento e afirmação da Reforma Protestante, não se detém nestes eventos históricos que antecederam o processo religioso, político, social, cultural que ocorreu a partir do século XVI, de forma pormenorizada, mas sim nas consequências de todos estes episódios, na medida em que produziram, nas pessoasdaquelaépoca,umsentimentodeculpa,visto que "a individuos e sociedades pesaram as cons- 
ciências e se sentiram culpados. Só o pecado poderia explicar tantas desgraças" (Delumeau, 1989, p. 60).

Surgia a ideia de que o juízo final e o castigo do inferno estavam cada vez mais próximos da realidade em que viviam os homens do Medievo. Mas, mais do que isso, todos estes acontecimentos, inclusive evidentemente a Peste Negra, reforçavam que seria "mais ainda do que o juízo final e o inferno, a morte [...] o grande tema da iconografia da Idade Média a findar. Incessantemente ressoa através da vida o apelo do memento mori” (Delumeau, 1989, p. 62).

Antes, porém, de avaliar a relação existente entre a iconografia medieval com a questão dos infortúnios pelos quais passavam os homens daquela época, tema que será caro a Delumeau, na medida em que procura analisar com exemplos a clara relação entre a epidemia e a iconografia da época, na obra O pecado e o medo - a culpabilização no Ocidente (séculos13-18), volume 1, Delumeau procura o lugar que se deve atribuir à Peste Negra na história da Europa entre os anos de 1348 a 1351.

Nesta obra, Delumeau (2003, p. 181) afirma que não se deve sugerir que todos os eventos históricos sejam necessariamente consequência única e exclusiva da Peste Negra, pensando também, conforme acima sugerido, na Reforma Protestante. Por outro lado, o impacto da Peste Negra na sociedade da época foi bastante expressivo, culminando na angústia coletiva de boa parte da população atingida e resultando em ações como as que ocorreram na reforma religiosa do século XVI. A respeito da primeira premissa, afirma Delumeau:

No século 19 e no início do 20, houve tendência a explicar tudo por ela [a peste]: as fraturas do sistema feudal, a crise da Igreja e, portanto, a trajetória para a Renascença e a Reforma. Em nossos dias, pelo menos na França, certos historiadores procuram antes minimizar o impacto da Peste Negra, sendo verdade, por um lado, que a erosão do sistema feudal e a deterioração da conjuntura econômica e social tinham começado antes, e por outro lado, que a civilização ocidental continuou sua marcha para frente a despeito desse violento ataque da doença (Delumeau, 2003, p. 181).

No entanto, Delumeau não minimiza a influência da Peste Negra na sociedade medieval. A fim de esclarecer a importância que a Peste Negra teve na vida em sociedade e no imaginário medieval, Delumeau elenca quatro ponderações que considera úteis no processo de compreensão da realidade da época, explicitados a seguir. 
Em primeiro lugar, destaca a impressionante severidade da epidemia, visto que "as estatísticas mais sóbrias para 1348-1351 levam a estimativa de mortalidade variando segundo locais de 25 a 40\%" (Delumeau, 2003, p. 182). Em segundo lugar, enfatizando o estudo da história das mentalidades, na verdade, conta mais o choque e a apreensão nos espíritos daquela época à possivel morte eminente do que propriamente o número de mortos. Em terceiro lugar, a peste poderia ser considerada mais um dos dramáticos acontecimentos do conjunto de desgraças que ocorriam ente os anos de 1348 a 1648. E, por fim, em quarto lugar, apesar de todo o infortúnio, a civilização europeia continuou a inovar em todos os seus domínios - no entanto, apesar dos avanços do século 16 - nada tenha se comparado efetivamente com o século das luzes ou a segunda metade do século 19 (Delumeau, 2003, p. 182).

Delumeau entende, desta forma, que a Reforma também pode ser compreendida envolta de todos estes eventos anteriores que colaboraram em seu processo de formação e contestação, sendo que, no entanto, não se pode atribuir a apenas uma causa - a Peste Negra - todo o processo reformista. Por outro lado, é evidente que também a Peste colaborou no imaginário medieval, na medida em que as mentes humanas, nestes tempos de calamidade, buscavam se aproximar de Deus e da salvação por ele oferecida. Isto especialmente se concretizou através de uma iconografia que destacava as agruras e também a possivel salvação através do Filho de Deus, Jesus Cristo, para o ser humano que passava por tamanho infortúnio.

\section{A Peste Negra no Medievo na visão de Jean Delumeau e as consequências na religiosidade da época}

Apesar de dedicar especial atenção à questão da história das mentalidades, procurando descrever o imaginário medieval sobre a Peste Negra, Delumeau não se isenta de informar, especialmente no capítulo 3, Tipologia dos comportamentos coletivos em tempos de peste da obra O Medo no Ocidente: 1300-1800, uma cidade sitiada, todo o processo histórico no qual a doença da Peste Negra atingiu a humanidade no tempo do Medievo.

Delumeau periodiciza o evento da Peste Negra que surge a partir do século VI da Era Cristã, avançando com grande força a partir do século XIV e estendendo-se com expressiva mortandade até o século XVIII, visto que, neste último século, "o mal se tornara mais esporádico e localizado, e depois de 1721 desapare- 
ceu do Ocidente" (Delumeau, 1993, p. 108). Para referenciar a ideia da presença cons-tante da Peste Negra, lembra da citação de Bennassar: "[a Peste Negra é] um grande personagem da história de ontem" (Delumeau, 1993, p. 108).

A respeito destes ciclos que marcaram a presença da Peste Negra, Delumeau assim descreve:

Uma leitura mais atenta dos textos da alta Idade Média permitiu recentemente concluir que a peste fora virulenta na Europa e em torno da bacia mediterrânica entre os séculos VI e VIII, com espécie de periodicidade dos surtos epidêmicos cujos picos se situavam a cada nove a doze anos. Depois ela pareceu desaparecer no século IX, mas para reaparecer brutalmente em 1346 nas margens do mar de Azov. Em 1347, atingiu Constantinopla e Gênova e logo toda a Europa, de Portugal e da Irlanda a Moscou. As devastações da "morte negra" estenderam-se pelos anos de 13481351, eliminando, assegura Froissard, "a terça parte do mundo" (Delumeau, 1993, p. 107).

Durante praticamente todo o século XIV até o limiar do século XVII, a peste continuou a ceifar a vida das pessoas na Europa Ocidental com relativa frequência. No entanto, pondera Delumeau que "a primeira peste geral ocorreu em 1348 e foi a mais forte" (Delumeau, 1993, p. 107). Ao mesmo tempo, Delumeau (1993, p. 108) destaca que, tomando Biraben por referência, se fôssemos acompanhar a história da peste, perceberíamos que, a cada oito, dez ou mesmo quinze anos, violentos surtos ocorriam e devastavam, em algumas situações, até mesmo cerca de $40 \%$ da população local. Refletindo sobre a população que foi atingida pela peste, Delumeau (1993, p. 108) declara que poderia se pensar que, aproximadamente, $1 / 3$ de toda a população da Europa foi atingida pela peste, ressaltando-se a severidade no número de mortos, principalmente na Itália, na França e na Inglaterra.

Delumeau também descreve a concepção que as pessoas do Medievo tinham a respeito da Peste Negra - quanto à sua forma de contágio e a maneira como pensavam em proteger-se da epidemia. Na visão da grande maioria das pessoas que viviam nestes tempos de epidemia da Peste Negra, a doença era consequência do ar contaminado, sendo que, somente no século XIX, houve compreensão mais apropriada dessas questões.

Até o final do século XIX, ignoraram-se as causas da peste que a ciência de outrora atribuía à poluição do ar, ela própria ocasionada seja por funestas conjunções astrais, seja por emanações pú- 
tridas vindas do solo ou do subsolo. Daí as precauções, aos nossos olhos inúteis, quando se aspergia com vinagre cartas e moedas, quando se acendiam fogueiras purificadoras nas encruzilhadas de uma cidade contaminada, quando se desinfetavam indivíduos, roupas velhas e casas por meio de perfumes violentos e de enxofre, quando se saía para a rua em período de contágio com uma máscara em forma de cabeça de pássaro cujo bico era enchido com substâncias odoríferas (Delumeau, 1993, p. 110).

Segundo descreve Delumeau (1993, p. 110), raramente as crônicas antigas e a iconografia indicavam como possiveis agentes de infecção as pulgas de ratos. No entanto, esclarece que "a história dessa doença desde às origens permanece ligada à do rato. Mas, em inúmeras epidemias de peste bubônica, [...] o principal agente de transmissão teria sido não o parasita murídeo, mas a pulga do homem passando de um hospedeiro agonizante para um hospedeiro são" (Delumeau, 1993, p. 111). A Figura 1 ilustra a realidade do enfrentamento da Peste Negra em conformidade com a citação de Delumeau (1993).

Figura 1: Médico com máscara antipeste negra

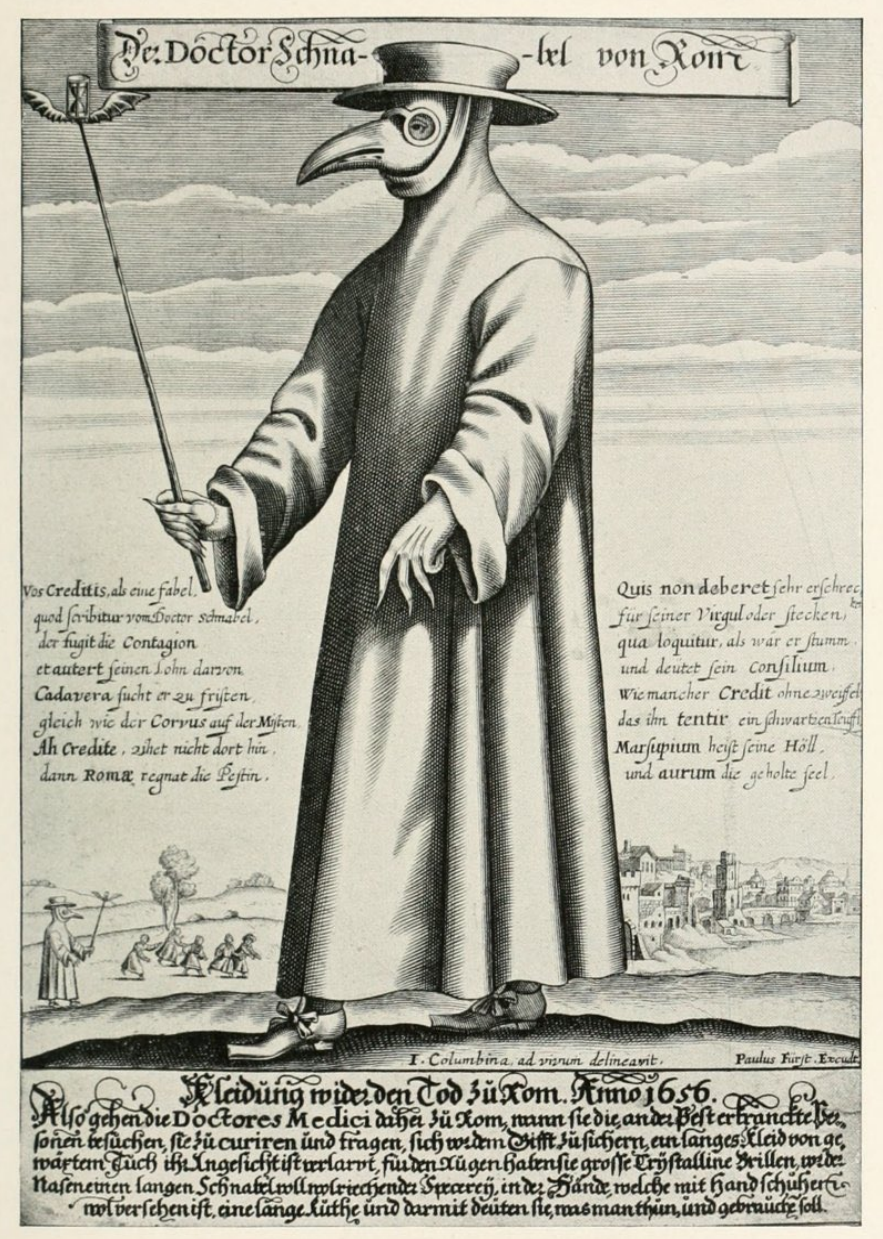

Fonte: Wikimedia Commons. Acesso em 10 de agosto de 2020 
Da mesma forma, Delumeau descreveu os principais sintomas da Peste quando atingia a população, sob a sua forma bubônica: "descrição dos 'carbúnculos', localização dos bubões, destaque dado, no quadro clínico, à língua intumescida, à sede ardente, à febre intensa, aos calafrios, à irregularidade do pulso, aos delírios muitas vezes violentos, às perturbações do sistema nervoso, às cefaleias, ao olhar fixo" (Delumeau, 1993, p. 110-111).

É importante se observar que, à semelhança do que ocorre no Tempo Presente com a Covid-19, também nas epidemias da Peste Negra a ordem deveria ser o isolamento, a fim de conter o contágio. No entanto, conforme descreve Delumeau, enquanto boa parte da população menos instruída procurava seguir à regra essa orientação, aqueles considerados eruditos recusavam-se a crer no contágio. " $\mathrm{E}$ foram afinal as medidas cada vez mais eficazes de isolamento que fizeram regredir o flagelo" (Delumeau, 1993, p. 111).

A respeito do surgimento da doença, os atingidos pela Peste entendiam que três poderiam ser as explicações para sua origem e proliferação. Para o grupo dos chamados "eruditos", a peste era provocada por fenômenos celestes (a aparição de cometas, a conjunção de planetas, entre outros fenômenos astrais), ou por emanações pútridas que infestavam o ar, ou mesmo por ambas as situações: "Quantos aos eruditos, por vocação e deformação profissionais, insistiam nas explicações 'naturais' pelos astros e pelo ar viciado, rejeitando por isso mesmo obstinadamente a noção de contágio (século XVI)" (Delumeau, 1993, p. 138). O mesmo sentimento ainda era compartilhado no século XVII pela maioria dos médicos da época.

Mas havia outra explicação "natural" para a epidemia da Peste Negra, desta vez, atrelada ao que se depositava na terra. É pertinente, desta feita, a observação da contaminação do ar, seja vinda do céu, seja vinda da terra:

a outra explicação "natural" (de resto não contraditória com a precedente) fazia derivar a peste de exalações malignas emanadas de cadáveres não enterrados, de depósitos de lixo, até das profundezas do solo. Todo um aspecto de profilaxia posto em obra pelas autoridades estava fundado na dupla teoria do ar viciado por cima, e por baixo que acabamos de lembrar: fogos e perfumes, máscaras protetoras, isolamento dos doentes e das casas contaminadas, limpeza das ruas, afastamento apressado de cadáveres, morte dos animais considerados suspeitos (Delumeau, 1993, p. 139).

Uma segunda sugestão de como se daria a contaminação da Peste Negra era usualmente divulgada pela multidão anônima. Nesta lógica, conforme explica 
Delumeau (1993, p. 138), a doença era espalhada de forma voluntária, sendo necessário identificar os responsáveis e puni-los. Delumeau (1993, p. 140) elenca uma lista de possiveis culpados da propagação da Peste Negra, segundo a massa da população da época. Nesta lista figuravam, em especial, todos aqueles que não estavam plenamente inseridos na sociedade, por exemplo, os estrangeiros, os viajantes, os marginais. Destaque se dava a judeus e leprosos: "[estes] foram efetivamente acusados, em 1348-1350, de terem espalhado a Peste Negra" (Delumeau, 1993, p. 140).

A respeito dos judeus, ocorreu grande perseguição, sendo estes acusados de "envenenar" o ar e a água para prejudicar a saúde dos demais moradores das aldeias e cidades.

A Peste Negra eclodiu então em uma atmosfera já carregada de antissemitismo. Tratando do resto da Europa e especialmente do império, o relato de Jean de Venette, onde a ordem dos fatos encontra-se modificadas em relação à realidade, fornece-nos a prova de que a opinião comum viu cada vez mais nos judeus os maiores responsáveis pela "morte negra". A ideia de que a morte provinha de uma infecção do ar e da água fez imputar aos judeus a corrupção dos poços, das águas e do ar. As pessoas insurgiram-se então cruelmente contra eles, a tal ponto que na Alemanha, e em outras partes onde habitavam judeus, numerosos milhares de judeus foram mortos, massacrados e queimados pelos cristãos (Delumeau, 1993, p. 140).

Apesar da forte perseguição a judeus como propagadores da Peste Negra, Delumeau (1993, p. 141) nota que, no seio da Igreja Cristã, não havia essa certeza. Muito pelo contrário, descreve, por exemplo, que o papa Clemente VI, em bula lançada em 26 de julho de 1348, invalida a ideia de contaminação proposital realizada pelos judeus, na medida em que também judeus eram atingidos pela epidemia ou que a peste assolava cidades, independente da presença de judeus residentes na localidade.

Por fim, ainda nessa visão a respeito dos culpados pela peste, recaíam muitas vezes desconfianças de que, no próprio interior da comunidade, pessoas poderiam ser semeadores voluntários da peste: "Qualquer um, a partir daí, pode ser considerado como um inimigo, e a caça aos feiticeiros e às feiticeiras escapava a todo o controle" (Delumeau, 1993, p. 143).

Um terceiro e último grupo composto por parte da multidão e pelos homens da Igreja via a peste como consequência de um Deus irritado com os peca- 
dos de toda a população: "São inúmeros os testemunhos que exprimiram através das eras esse discurso religioso sobre a desgraça coletiva segundo o qual todo mundo é culpado e não apenas alguns bodes expiatórios" (Delumeau, 1993, p. 144). Delumeau, inclusive, afirma ser esse o pensamento de Lutero que dizia ser a Peste "um decreto de Deus, um castigo enviado por ele" (Delumeau, 1993, p. 144).

Segundo Delumeau (1993, p. 145), em face desta realidade, da Peste como um castigo de Deus, restava ao bom cristão ter duas atitudes em especial: em primeiro lugar, deveria estar ciente de sua pecaminosidade, aceitando com docilidade a punição imposta por Deus, ou seja, não deveria ter medo de morrer. Em segundo lugar, o ser humano, a fim de aplacar a "justa ira" de Deus em face do seu pecado, deveria ter duas atitudes em especial: corrigir a sua vida e fazer penitência a Deus.

No entanto, iniciativas individuais não eram suficientes, visto que se entendia que a culpa era de todos os moradores da cidade atingidos pela peste. Dentro desta lógica, Delumeau lembra que as procissões impressionavam quantitativamente, haja vista o número expressivo de pessoas que participavam de tais atos religiosos, bem como reflete sobre o que a ela estava diretamente ligado:

tais procissões impressionam por vários aspectos [...] constituem cerimônias penitenciais: uma população inteira confessa suas faltas e implora perdão. O clero canaliza e controla as manifestações expiatórias que, no tempo da Peste Negra, tinha dado lugar às histéricas e sangrentas vagueações dos flagelantes (Delumeau, 1993, p. 147).

Como as procissões necessitavam percorrer todas as ruas e como comparecia uma multidão de pessoas, duravam longo período do dia. Mas, segundo Delumeau, esse tempo, acima de tudo, antes de representar somente uma profunda reflexão e arrependimento diante de Deus, por parte daqueles que estavam envolvidos, também denotava a ideia de que: "é preciso que uma cerimônia religiosa seja longa. [...] uma súplica em tal perigo só tem possibilidade de ser escutada pelo Céu se se prolonga suficientemente para forçar a atenção e a compaixão do Juiz encolerizado" (Delumeau, 1993, p. 148).

Em face de um perigo tão grande e ameaçador, as pessoas recorriam a todas as possibilidades de proteção, especialmente Maria e seu Filho, Jesus Cristo. É interessante, no entanto, pontuar, que Delumeau reflete a ideia de que as pessoas do Medievo muitas vezes compreendiam que Jesus estivera ligado mais à 
ideia de "ira divina" do que necessariamente de compaixão. Diferente era a opinião sobre Maria, visto que "as pessoas se persuadiam de que Maria jamais participa da cólera divina e de que só intercede para abrandar a justiça rigorosa de seu Filho" (Delumeau, 1993, p. 150).

Também se recorriam aos santos a fim de que intercedessem em favor dos homens diante do Deus Altíssimo. Em especial, eram considerados os santos antipestilentos: São Sebastião e São Roque. Delumeau (1993, p. 150) descreve a confiança que se tinha em São Roque, visto que, na lenda a respeito de sua qualificação de santo, encontrava-se a descrição: "eris in pestis patronus", traduzida por "tu serás na peste o protetor". Acrescente-se que a São Roque e São Sebastião, ainda cerca de outros cinquenta santos antipestilentos de menor envergadura poderiam ser invocados.

Porém, Delumeau conclui que, apesar desta expressão de fé, havia, por parte dos fiéis abatidos pela Peste Negra, um sentimento denominado por ele de "incúria do abatimento", ou seja, "preces, missas, votos, jejuns e procissões não podiam tudo. Se a epidemia continuava igualmente virulenta, as pessoas se instalavam doravante numa espécie de torpor, já não tomavam precauções, negligenciavam seu aspecto: era a incúria do abatimento" (Delumeau, 1993, p. 150).

\section{O imaginário religioso e a Peste Negra na iconografia medieval}

Delumeau, em seus textos sobre o imaginário medieval e sua relação com os diversos acontecimentos que marcaram a época, inclusive a Peste Negra, descreve a importância de uma iconografia marcante que simbolizava e expressava a "angústia coletiva" das pessoas, especialmente relacionadas com a temática da morte.

$\mathrm{Na}$ iconografia medieval, a figura da morte está sempre presente. Delumeau $(1989$, p. 62) identifica algumas figuras que personificavam a morte no Medievo, por exemplo: um "sinistro velho" carregando uma ampulheta no mundo indicando o pouco tempo de vida do ser humano; uma "megera" com asas de morcego; ou um esqueleto "caricato" com foice ou flechas num carro puxado por bois.

Surgia também toda uma literatura baseada no "conto dos três vivos e dos três mortos". Segundo Delumeau, "no fim do século XIII tinha nascido na Itália o tema dos Três mortos e dos três vivos: três jovens nobres ricamente vestidos encontram bruscamente três mortos já roídos pelos vermes que lhes contam sua 
grandeza passada e anunciam aos moços seu próximo fim" (Delumeau, 1989, p. 62).

Entendeu Delumeau também que toda uma iconografia personificada com as chamadas "danças macabras" - ver Figura 2 - que se avolumaram, principalmente no século XV, evidenciavam a preocupação que o ser humano tinha com o seu destino final. Tal relação não se dava apenas na pintura e escultura, mas na literatura da época também.

A dança macabra não foi somente pintada e gravada. Ela foi executada também. [...] A Igreja se esforçou por dar ênfase, numa sociedade perseguida pelo temor da morte, ao momento em que se trava o último combate da vida terrena em que se decide a sorte eterna da alma. Assim se explicam as numerosas edições (uma centena entre 1465 e 1500) da Ars moriendi [...]. O moribundo aparece aí rodeado pelos anjos e demônios. Estes se afadigam à volta do moribundo debilitado. Querem fazê-lo duvidar, induzi-lo ao desespero, prendê-lo uma última vez às riquezas que se escapam, levá-lo a blasfemar, depois a se refugiar na suficiência e orgulho. Mas os anjos ajudam o paciente a resistir a estas [...] tentações (Delumeau, 1989, p. 63).

Figura 2: A dança macabra

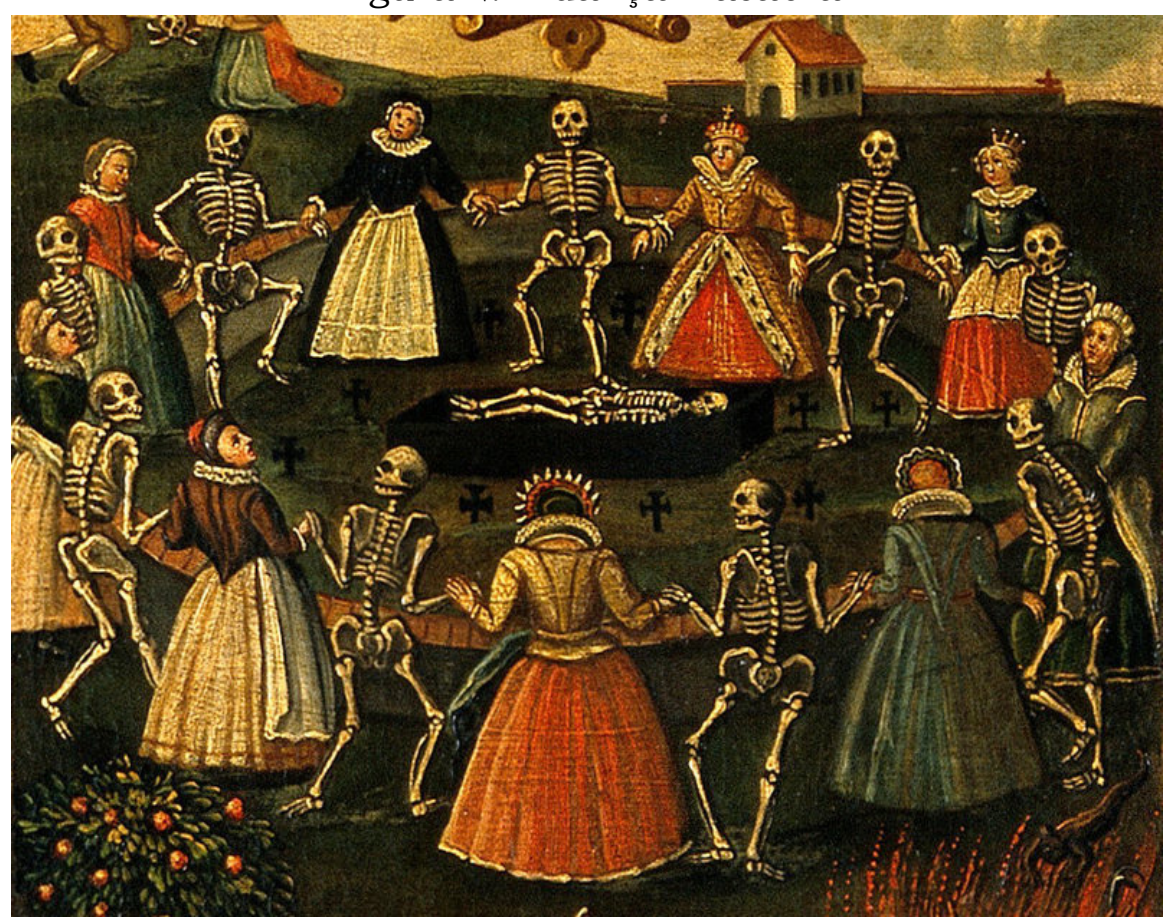

Fonte: https://tendimag.com/tag/danca-macabra/. Acesso em 10 de agosto de 2020

Desta feita, a peste acabava sendo incorporada em uma cronologia do macabro: "Ela se integra numa mesma explicação global em que confluem o discur- 
so culpabilizador, o pavor diante dos infortúnios acumulados e a violência presente em toda a parte" (Delumeau, 2003, p. 179).

Outras formas de como a peste era representada na iconografia medieval possuiam grande relevância no imaginário da Idade Média, sendo assim lembrada e analisada por Delumeau:

A Peste comparável a outros dois flagelos tradicionais: a fome e a guerra. A peste é então uma "praga" comparável a que atingiu o Egito. É ao mesmo tempo identificada como uma nuvem devoradora vinda do estrangeiro e que se desloca de país em país, semeando a morte à sua passagem. É ainda descrita como um dos cavaleiros do Apocalipse, como um novo "dilúvio", como um "inimigo" formidável e sobretudo como um incêndio frequentemente anunciado no céu pelo rastro de fogo de um cometa (Delumeau, 1993, p. 112).

No entanto, acima de tudo, para os religiosos da época e para os artistas do Medievo, a representação que mais definia o significado da Peste Negra podia ser visualizada através de uma chuva de flechas abatendo-se sobre os homens, apontando para um Deus irado e encolerizado com a decadência humana. Essa representação, na verdade, não era algo novo, visto que, já no final do século XIII, temos a representação da visão "de São Dominique percebendo do céu o Cristo irado que bradia três lanças contra a humanidade culpada de orgulho, de cupidez e de luxúria" (Delumeau, 1993, p. 113).

Delumeau (1993, p. 114) entende que tanto o clero quanto os fiéis, de modo geral, acabaram, ao longo dos séculos, absorvendo a ideia da punição de Deus, através de flechas lançadas do alto. Variantes desse pensamento eram encontradas também na iconografia, em que, ao invés de Deus, as flechas eram lançadas pela própria morte.

Também as representações dos santos que morriam por ferimentos causados por flechas contemporizavam a ideia de serem santos protetores contra a peste, visto ser um mal lançado dos céus. Delumeau lembra o exemplo de um dos principais santos antipestilentos da época, São Sebastião, quando afirma:

Porque São Sebastião morrera crivado de flechas, as pessoas convenceram-se de que ele afastava de seus protegidos as da peste. Desde o século VII, ele foi invocado contra as epidemias. Mas foi depois de 1348 que seu culto ganhou um grande impulso. E desde então, no universo católico até o século XVIII inclusive, quase 
não houve igreja rural ou urbana sem uma representação de São Sebastião crivado de flechas (Delumeau, 1993, p. 116).

Delumeau entende que a força que a Peste Negra teve na sociedade daquela época, sintetizada através de uma iconografia marcante, não apenas simbolizava o sofrimento humano e a punição divina, mas que também identificava a morte como o agente central desse processo. Citando Millard Meiss, Delumeau entendeu que a "Peste Negra foi um 'evento cultural', em particular no domínio da pintura religiosa" (Delumeau, 2003, p; 182) que se evidencia pelo retrato da morte em questão.

Delumeau, em seus trabalhos sobre a Peste Negra e a iconografia da época, enfatizou uma série de exemplos, destas representações da morte. Lembra do "célebre afresco do Campo Santo de Pisa (por volta de 1350) que cumula triunfo da Morte, na lenda dos três mortos e três vivos, julgamento e inferno" (Delumeau, 2003, p. 182).

Os vinculos entre a Peste Negra e as danças macabras, por exemplo, foram inúmeros. Segundo Delumeau, "Aos olhos dos contemporâneos, três características das epidemias de peste deviam aparecer expressas pelas danças macabras: o aspecto punição divina, a brutalidade do ataque mortal e a igualdade na morte que reduzia à mesma sorte ricos e pobres, jovens e velhos" (Delumeau, 2003, p. 185).

No entanto, mais que simplesmente a representação da morte, entende Delumeau (2003, p. 185) que a grande mensagem da iconografia medieval a respeito da Peste Negra e suas consequências na vida das pessoas daquela época pode ser identificada numa iconografia do Triunfo da morte. Para tanto, a obra que melhor expressa essa realidade, segundo Delumeau, pode ser identificada na pintura O Triunfo da morte, de Peter Brueghel:

Mas é a Brueghel, o Velho, que se deve a mais poderosa evocação do Triunfo da Morte (por volta de 1562, Prado) [...]. A moralidade é sempre aquela das danças macabras e da lenda dos três mortos e três vivos: prazeres, riqueza e glória não contam mais quando a vida se extingue. Mas a demonstração é dada por uma alucinante e fervilhante visão do pesadelo (Delumeau, 2003, p. 185). 
Figura 3: O Triunfo da Morte - autor: Pieter Brueghel

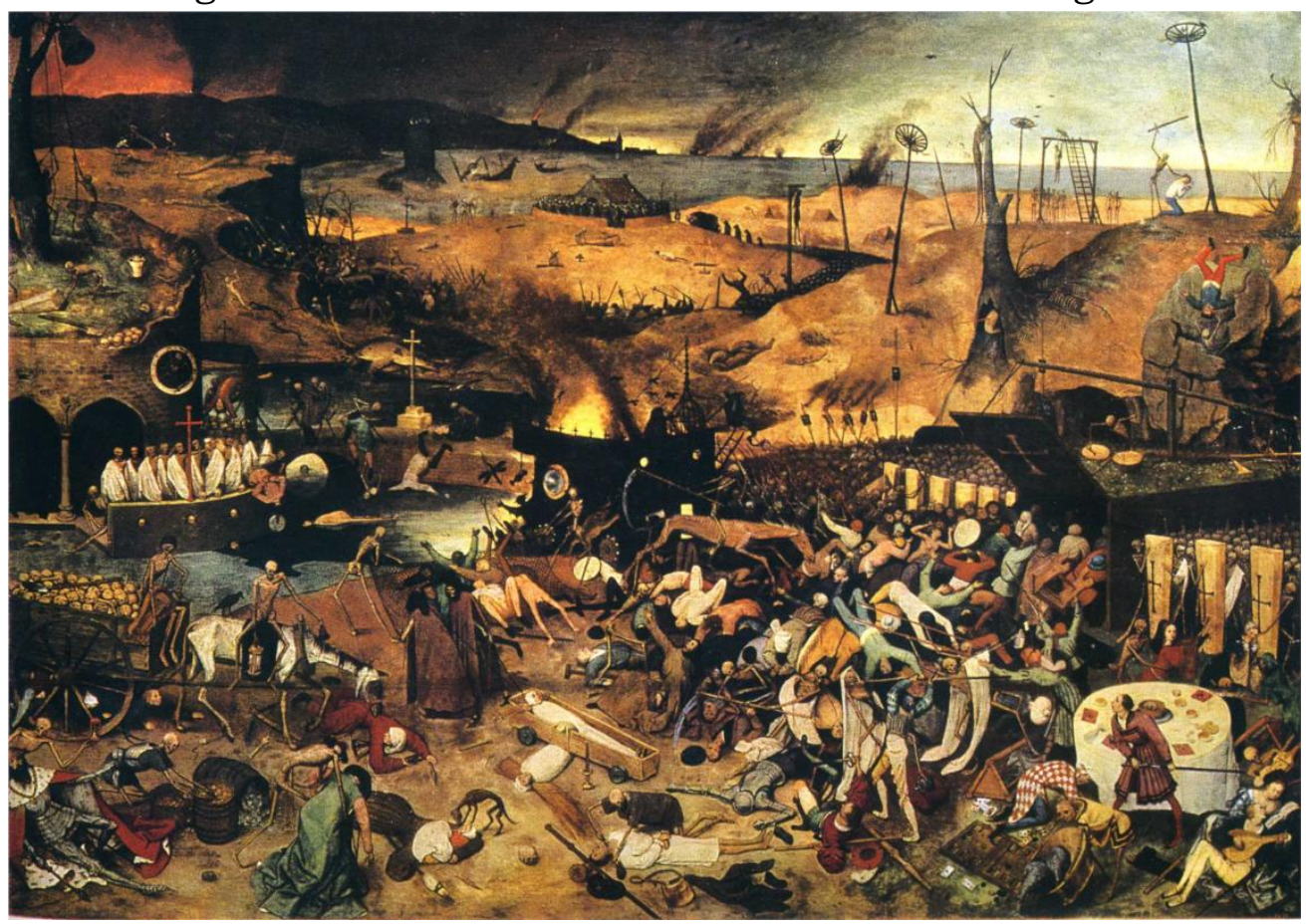

Fonte: http://warburg.chaa-unicamp.com.br/obras/view/6005. Acesso em 10 de agosto de 2020

A Peste que ceifou a vida de milhares de pessoas nos tempos de Medievo, por certo, em determinado momento cessou. O que fizeram os homens do medievo, que viviam "uma grande angústia coletiva" quando esse momento se encerrou? Delumeau cita interessante apontamento feito por Jean de Venette que assim afirmou sobre a pós-epidemia de Peste Negra na Europa Medieval.

Quando a epidemia, a pestilência e a mortalidade tinham cessado, os homens e as mulheres que restavam casavam-se sucessivamente. As mulheres sobreviventes tiveram um número extraordinário de filhos [...]. Aî!, dessa renovação do mundo, o mundo não saiu melhorado. Os homens foram depois ainda mais cúpidos e avaros, pois desejavam possuir bem mais do que antes; tornados mais cúpidos, perdiam o repouso nas disputas, nos ardis, nas querelas e nos processos. Tinha-se esquecido o medo; mas por quanto tempo? (Delumeau, 1993, p. 150).

Essa mesma pergunta soa atual, no Tempo Presente, quando a humanidade se prepara para viver a pós-pandemia da Covid-19. No "novo normal", se- 
remos melhores pessoas, haverá uma nova mentalidade na sociedade contemporânea? Voltaremos a incorrer na vida normal "sendo homens cúpidos e avaros"?

\section{Considerações finais}

Neste artigo, procurou-se compreender a visão que um dos grandes historiadores da História da Igreja e das mentalidades, Jean Delumeau, possuía a respeito de questões relacionadas ao medo no Ocidente, neste caso, resultante da Peste Negra. Delumeau, de forma magistral, levou-nos à consciência das pessoas do medievo, em face de tão grande desgraça que atingiu as vidas humanas, e que foi representada numa iconografia deveras importante.

Concordamos, desta feita, com Delumeau em seus estudos sobre a importância que a iconografia medieval teve na compreensão do pensamento a respeito da Peste Negra e de suas consequências na vida do medievo. As representações que apontavam para um Deus irado e principalmente para a vitória da morte retratavam a percepção que se tinha sobre os trágicos eventos históricos pelos quais os homens daquela época passavam, reflexos de um periodo de grande angústia coletiva.

Concluímos, assim, com as palavras de Jean Delumeau, em sua obra $\grave{A}$ espera da Aurora: Um Cristianismo para o amanhã, lançado em língua portuguesa no ano de 2007. Nesta obra, Delumeau, um cristão católico e um historiadorcientista, não trata da Peste Negra, mas sim das implicações do Cristianismo no Tempo Presente. No entanto, a mesma "angústia coletiva" da época do medievo pode ser visualizada em novas formas, como a própria pandemia da Covid-19, o terrorismo, a violência, a discriminação, entre outras.

Para todos nós, após sua partida neste icônico ano de 2020, Delumeau deixa uma palavra: "Pois, segundo o cristianismo, os homens são irmãos de Cristo e co-herdeiros com ele do reino de Deus. Em razão disso, fundamentalmente, todos são iguais; todos eles são chamados ao mesmo destino da divinização última. E Jesus avisou solenemente que ele se identificava com os doentes, os pobres e os prisioneiros" (Delumeau, 2007, p. 206).

\section{Referências bibliográficas}

BURKE, Peter. A Escola dos Annales (1929-1989): a Revolução Francesa da historiografia. São Paulo: Editora da UNESP, 1997. 
CARVALHO Bruno Leal Pastor de. Morre o historiador francês Jean Delumeau, autor do clássico "História do Medo no Ocidente" (notícia). In: Café História- História feita com cliques. Disponivel em: https://www.cafehistoria.com.br/morre-ohistoriador-jean-de-delumeau. Acesso: 10 de agosto de 2020.

DELUMEAU, Jean. À espera da aurora: Um cristianismo para o amanhã. São Paulo: Edições Loyola, 2007.

DELUMEAU, Jean. História do medo no Ocidente: 1300-1800, uma cidade sitiada. São Paulo: Companhia das Letras, 1993.

DELUMEAU,Jean.NascimentoeafirmaçãodaReforma. São Paulo: Pioneira, 1989.

DELUMEAU, Jean. O pecado e o medo: a culpabilização no Ocidente (séculos 1318). vol. 1, Bauru: EDUSC, 2003.

FUNDAÇÃO OSWALDO CRUZ (FIOCRUZ). Por que a doença causada pelo novo virus recebeu o nome de Covid-19? Disponivel em: https://portal.fiocruz.br/per gunta/por-que-doenca-causada-pelo-novo-virus-recebeu-o-nome-de-covid-19. Acesso em 10 de agosto de 2020.

INSTITUTO HUMANITAS UNISINOS. Como Jean Delumeau via o futuro do cristianismo. Revista IHU online. Unisinos, 22 de janeiro de 2020. Disponivel: http:// www.ihu.unisinos.br/78-noticias/595790-como-jean-delumeau-via-o-futuro-docristianismo. Acesso em 10 de agosto de 2020.

INSTITUTO HUMANITAS UNISINOS. Jean Delumeau: um historiador entre o medo e a esperança. Revista IHU online. São Leopoldo: Unisinos, 31 de janeiro de 2020. Disponivel em: http://www.ihu.unisinos.br/78-noticias/596038-jean-delu meau-um-historiador-entre-o-medo-e-a-esperanca. Acesso em 10 de agosto de 2020.

PIERONI, Geraldo. Jean Delumeau: historiador do passado e do presente cristão. In: Anais do XXVI Simpósio Nacional de História - ANPUH, São Paulo, julho 2011.

Recebido em 19/10/2020 Aceito para publicação em 23/02/2021 